\title{
REGULASI DIRI SEBAGAI PREDIKTOR STRES AKADEMIK MAHASISWA BEKERJA PARUH WAKTU
}

\author{
Dewi Indah Nurcahyani, Endang Prastuti
}

\author{
* Corresponding Author: \\ Universitas Negeri Malang \\ Email: \\ dewigeonurcahyani9927@gmail. \\ com; \\ endangprastuti12@gmail.com
}

\begin{abstract}
Abstrak.Proses pengerjaan skripsi bukanlah suatu yang mudah dilalui mahasiswa dan banyak kendala yang dihadapi, apalagi untuk mahasiswa yang sedang mengerjakan skripsi yang bekerja paruh waktu. Tekanan-tekanan dan harapan yang berhubungan dengan penyelesaian skripsi merupakan salah satu sumber stres yang sering dialami oleh mahasiswa. Stres pada mahasiswa yang mengerjakan skripsi termasuk stres akademik. Stres akademik pada mahasiswa yang bekerja paruh waktu dapat menganggu proses penyelesaian skripsi. Beberapa penelitian menyebutkan bahwa regulasi diri menjadi salah satu bentuk strategi coping stres untuk mencegah timbulnya stres akademik. Penelitian ini bertujuan untuk mengetahui hubungan antara regulasi diri dengan stres akademik pada mahasiswa skripsi Universitas Negeri Malang yang bekerja paruh waktu. Subjek dipilih menggunakan metode proporsional stratified sampling, dengan kriteria mahasiswa skipsi Universitas Negeri Malang yang bekerja paruh waktu. Subjek penelitian berjumlah 43 mahasiswa. Instrumen Regulasi Diri memiliki reliabilitas 0,888 dan Skala Stres Akademik adaptasi dari Lin dan Chen (2009) memiliki reliabilitas 0,826 . Menggunakan analisis korelasi product moment pearson dan analisis regresi sederhana diperoleh hasil bahwa terdapat hubungan negatif antara regulasi diri dengan stres akademik pada mahasiswa skripsi Universitas Negeri Malang. Sumbangan pengaruh regulasi diri terhadap stres akademik sebesar $21,3 \%$ sisanya dipengaruhi oleh faktor lain.
\end{abstract}

Kata Kunci: regulasi diri; stres akademik

Abstract. The thesis process is not an easy thing for a student to pass and many obstacles are encountered, especially for thesis students who work part time. Pressures and expectations related to the completion of the thesis is one source of stress that is often experienced by students. Stress on students working on their thesis, including academic stress. Academic stress on undergraduate students who work part-time can disrupt the process of completion of the thesis. Some studies suggest that self-regulation is a form of stress coping strategy to prevent academic stress. This study aims to determine the relationship between self-regulation and academic stress in undergraduate thesis students of Malang State University who work part time. Subjects were selected using the proportional standard sampling method, with the criteria for students of Malang State University who work part time. Research subjects were 43 students. The Self Regulatory Instrument has a reliability of 0.888 and the Academic Stress Adaptation Scale from Lin and Chen (2009) has a reliability of 0.826. Using Pearson product moment correlation analysis and simple regression analysis results show that there is a negative relationship between self-regulation and academic stress on undergraduate students at State University of Malang. The contribution of self-regulation to academic stress by the remaining $21.3 \%$ is influenced by other factors.

Keyword: self regulation; academic stress 


\section{PENDAHULUAN}

Merujuk pada life span perspective, mahasiswa berada di tahap peralihan dari tahap remaja menuju tahap dewasa, disebut juga tahap beranjak dewasa (emerging adulthood), dengan rentang usia 18-25 tahun. Periode ini individu mulai melepaskan ketergantungan terhadap orang lain, akan tetapi belum memiliki tanggung jawab yang dimiliki orang dewasa (bekerja \& berkeluarga) (Arnett, 2000) Masa emerging adulthood memiliki beberapa ciri: (a) mengeksplorasi identitas khususnya dalam relasi romantis dan pekerjaan, (b) usia yang penuh ketidkstabilan, (c) fokus pada diri sendiri, untuk memperoleh pemahaman dan belajar mandiri, (d) merupakan usia antara tidak lagi remaja dan belum sepenuhnya dewasa, (e) belum mapan dan stabil, serta memiliki banyak peluang merubah hidup (Arnett, 2004).

Ditinjau dari konteks akademik, usia mahasiswa (college), terjadi perubahan jenjang pendidikan dari pendidikan menengah ke perguruan tinggi biasanya mahasiswa merasa lebih dewasa, mempunyai banyak pilihan terhadap mata kuliah yang ingin diambil, memiliki kesempatan lebih besar untuk mengeksplorasi dan gaya hidup, lebih merasa tertantang secara intelektual dan tugas akademik, akan tetapi pada masa peralihan tersebut banyak problematic, salah satunya adalah terkait akademik. Problematik akademik ditandai dengan kewajiban mahasiswa mengerjakan: praktikum, tugas kelompok, serta pengerjaan tugas akhir (skripsi), yang merupakan karya tulis ilmiah (penelitian) sesuai dengan bidang studi yang ditulis pada akhir program studi sebagai salah satu syarat mendapat gelar bagi mahasiswa program S1 (Sujana, 1998).

Mahasiswa tingkat akhir yang menyelesaikan studi diharapkan tetap fokus dalam menyelesaikan skripsi agar dapat mencapai target yang telah ditetapkan. Penyelesaian skripsi biasanya dilakukan pada semester ke delapan dan dilakukan selama satu semester. Ditengarai, ada fenomena mahasiswa yang memilih studi dengan kerja paruh waktu, karena mahasiswa memiliki kebebasan untuk menentukan pilihan yang diinginkan dan memiliki kontrol yang besar dalam kehidupannya. Mahasiswa yang sedang proses mengerjakan skripsi dengan bekerja paruh waktu, diharapkans berpikir dengan cermat dan memiliki kemampuan dalam membagi waktu dan merancang strategi agar tidak berdampak pada penyelesaian skripsi. Ter- dapat perbedaan usia remaja dan dewasa awal dalam aspek kognitif, ketika remaja individu mulai mampu menyusun rencana dan hipotesis, namun di masa dewasa awal, kemampuan yang dimiliki menjadi lebih sistematis dan terampil (Piaget, dalam Santrock, 2011). Namun, fakta empiris menunjukkan fenomena yang menarik: mahasiswa yang sedang memprogram skripsi dan bekerja paruh waktu, ditengarai mengalami kesulitan dalam proses penyelesaian skripsi dan berdampak pada munculnya stres, yang disebut dengan stres akademik (academic stress).

Hasil studi pendahuluan dilakukan pada 40 orang mahasiswa Universitas Negeri Malang, dengan kriteria: (a) sedang mengerjakan skripsi, (b) bekerja paruh waktu. Temuan penelitian menunjukkan: tingkat stres yang dialami mahasiswa dalam kategori berat $55 \%$, stres tingkat sedang 27,5 \% dan stres tingkat rendah 17,5 $\%$, dengan kata lain mahasiswa yang sedang mengerjakan skripsi dan bekerja paruh waktu sebagian besar mengalami stres berat. Penelitian lain menguatkan fenomena ini: bahwa mahasiswa mengalami stres sangat berat $(22,6 \%)$, stres berat $(25,8 \%)$ sedangkan sisanya merasakan stres normal $(23,1 \%)$, stres sedang $(15,8 \%)$, stres ringan sebesar 12,7\% (Arsaningtias, 2017). Penelitian lain dengan responden mahasiswa Universitas Tribhuana Tunggadewi Malang, sebagian besar $(56,52 \%)$ mengalami stress berat (Hamadi, dkk., 2018). Data-data ini menguatkan fakta ketika sedang mengerjakan skripsi sebagian besar mahasiswa mengalami stress dan tekanan yang berat, dari aspek akdemik, hal ini menjadi semakin kuat stress yang dialami ketika mahasiswa bekerja paruh waktu.

Telaah literatur menguatkan fakta bahwa tekanan-tekanan dan harapan yang berhubungan dengan penyelesaian skripsi merupakan salah satu sumber stres yang sering dialami oleh mahasiswa (Govaerst \& Gregoire, 2004). Stres merupakan suatu kondisi yang menekan psikis seseorang dalam mencapai sesuatu kesempatan untuk mencapai kesempatan tersebut terdapat batasan atau penghalang (Robbins, 2001). Stres yang dialami mahasiswa yang sedang mengerjakan skripsi termasuk stres akademik, yakni stres yang muncul karena adanya tekanan-tekanan untuk menunjukkan prestasi dan keunggulan dalam kondisi persaingan akademik yang semakin meningkat sehingga semakin terbebani dengan berbagai tekanan dan tuntutan (Alvin, 2007). 
Penelitian menguatkan fakta bahwa 78,3\% mahasiswa mengalami stres dengan penyebab utama yaitu beban akademik yang cukup tinggi (Rahman, dkk., 2013), sementara itu faktor yang disebut dengan regulasi diri, dapat mengurangi stres dan frustasi serta mempermudah pelaksanaan strategi pemecahan masalah (Ayduk, dkk., 2000). Regulasi diri merupakan penggunaan suatu proses yang mengaktivasi pemikiran, perilaku dan perasaan yang terus menerus dalam upaya untuk mencapai tujuan yang telah ditetapkan (Schunk \& Zimmerman, 1998), singkat kata, regulasi diri merupakan kemampuan mengatur dan mengendalikan perilaku manusia (Hergenhann, 1984).

Regulasi diri yang berjalan efektif akan mengarahkan suatu perilaku mahasiswa dalam proses mencapai kesuksesan. Ahli lain menyatakan bahwa regulasi diri diartikan sebagai suatu proses dalam menghasilkan pikiran, tindakan yang terencana oleh diri dan terjadi secara berkesinambungan sesuai dengan upaya pencapaian tujuan (Zimmerman, 2000). Dengan demikian, sejatinya regulasi diri memiliki peranan penting bagi kehidupan akademik mahasiswa karena regulasi diri memiliki sifat proaktif menjadikan individu untuk terarah pada pencapaian tujuan, oleh karena itu regulasi diri merupakan salah satu faktor peredam tingkat stres pada mahasiswa tingkat akhir yang sedang mengerjakan skripsi.

Hasil penelitian terhadap mahasiswa (dengan status menikah) di Universitas Syiah Kuala, membuktikan terdapat hubungan negatif yang signifikan antara regulasi diri dengan stres pada mahasiswa., artinya ketika mahasiswa memiliki tingkat regulasi diri yang rendah maka tingkat stres yang dimiliki tinggi. Indikasi regulasi diri yang rendah ditandai dengan: ketidakmampuan mengontrol dan mengatur diri secara efektif, sehingga berdampak terhadap ketidakmampuan membuat strategi-strategi dan perencanaan untuk setiap kegiatan yang dilakukan sebagai upaya untuk pencapaian tujuan (Agustia, 2014).

Hasil penelitian terdahulu pada responden mahasiswa telah membuktikan peran regulasi diri dan stres akademik, misalnya pada responden mahasiswa kedokteran (Wulandari, 2018), juga pada responden mahasiswa yang telah menikah (Agustia, 2014). Penelitian terkait stres akademik pada mahasiswa, yang juga bekerja paruh waktu telah dikaji pula dengan mengkaitkan faktor kepribadian hardiness (Setiawan,
2019). Mengingat fenomena stres akademik pada mahasiswa yang sedang memprogram skripsi dan bekerja paruh waktu, ditengarai mengalami stres akademik yang tinggi, maka peran regulasi diri menjadi penting. Regulasi diri merujuk pada kemampuan untuk mengelola dan mengatur diri yang terarah pada tujuan yang akan dicapai, dipandang bahwa kemampuan ini bisa ditingkatkan, dipelajari dan dilatihkan, dibandingkan ketika melibatkan aspek kepribadian, yang merupakan kecenderungan yang relatif tetap.

Tujuan penelitian ini: (1) Mengetahui hubungan regulasi diri dengan stress akademik pada mahasiswa yang sedang memprogram skripsi, yang bekerja paruh waktu, (2) Mengetahui seberapa besar sumbangan regulasi emosi terhadap stres akademik pada mahasiswa yang sedang memprogram skripsi, yang bekerja paruh waktu. Penelitian ini penting untuk dilakukan untuk menjawab problematik empiris stres akademik pada mahasiswa yang memprogram skripsi, yang bekerja paruh waktu, khususnya mahasiswa di Universitas Negeri Malang.

\section{METODE}

\section{Desain Penelitian}

Penelitian ini menggunakan metode penelitian kuantitatif dengan rancangan yang digunakan dalam penelitian ini yaitu deskriptif korelasional. Hal ini ditujukan untuk mengetahui gambaran mengenai regulasi diri dan stres akademik, serta untuk mengungkap hubungan korelatif antar kedua variabel tersebut. Populasi dalam penelitian ini yaitu mahasiswa skripsi Universitas Negeri Malang yang bekerja paruh waktu. Data populasi yang diperoleh yaitu berjumlah 107 mahasiswa. Teknik pengambilan sampel menggunakan proportional stratisfied sampling dengan ratio $40 \%$ sehingga diperoleh jumlah sampel berjumlah 43 mahasiswa.

\section{Instrumen Penelitian}

Penelitian ini menggunakan dua jenis instrumen. Regulasi diri diukur menggunakan skala regulasi diri yang disusun berdasarkan aspek-aspek regulasi diri menurut Zimmerman (1995) yang terdiri dari 3 aspek yaitu: metakognisi, motivasi, dan perilaku. Metakognisi adalah merencanakan, mengorganisasi, mengukur diri dan menginstruksi diri sebagai kebutuhan selama proses berperilaku. Motivasi adalah fungsi dari kebutuhan dasar untuk mengontrol dan berkaitan dengan kemampuan yang ada pada setiap individu. Perilaku merupakan upaya untuk 
mengatur diri, menyeleksi dan memanfaatkan lingkungan maupun menciptakan lingkungan yang mendukung aktivitas yang dilakukannya. Skala regulasi diri terdiri dari 14 pernyataan favorabel dan 15 pernyataan unfavorabel dengan reliabilitas dengan Alpha Cronbach sebesar 0,888 .

Stres akademik diukur menggunakan skala stres akademik yang diadaptasi dari skala stres akademik Lin dan Chen (2009) yang disusun berdasarkan faktor-faktor stres akademik yang terdiri dari stres dari guru, stres dari hasil, stres dari tes, stres dalam kelompok belajar, stres sebaya, stres manajemen waktu dan stres yang diakibatkan oleh diri sendiri. Skala stres akademik berjumlah 19 pernyataan dengan reliabilitas dengan Alpha Cronbach sebesar 0,862.

Menurut Beaton (2000) pengadaptasian instrumen dilakukan dengan beberapa tahap, antara lain: translate bahasa yang dilakukan oleh dua penerjemah dari bahasa inggris ke bahasa indonesia. Synthesis, terjemahan direview dan bahasa yang akan digunakan diperhalus. Back translation, hasil synthesis diterjemahkan kembali ke bahasa inggris. Skala back translation direview oleh ahli bahasa dengan membandingkannya dengan skala asli untuk diperoleh kesamaan makna atau menilai ke equivalen pada setiap aitem. Uji terbatas, skala diujikan ke sampel kecil ( $\mathrm{n}=3$ responden) untuk melihat pemahaman kalimat dalam setiap aitemnya. Uji coba lapangan untuk mengetahui validitas pada setiap aitem dan reliabilitas skala.

\section{Analisis Data}

Analisis data dalam penelitian ini menggunakan analisis deskriptif, analisis korelasional menggunakan product moment pearson atau analisis regresi sederhana. Analisis deskriptif digunakan untuk mengungkap gambaran regulasi diri dan stres akademik. Analisis korelasional digunakan untuk mengetahui hubungan antara regulasi diri dan stres akademik. Analisis regresi sederhana digunakan untuk mengetahui hubungan antara regulasi diri dan stres akademik serta untuk mengetahui besarnya sumbangan pengaruh regulasi diri terhadap stres akademik.

\section{HASIL DAN PEMBAHASAN \\ Hasil \\ Analisis Deskriptif Regulasi Diri}

Berikut tabel klasifikasi hasil penelitian dari variabel regulasi diri:
Tabel 1. Klasifikasi dan Frekuensi Regulasi Diri

\begin{tabular}{llll}
\hline Klasifikasi & Rumus & $f$ & $\%$ \\
\hline Tinggi & $\mathrm{Z}>0$ & 19 & $44,19 \%$ \\
Rendah & $\mathrm{Z}<0$ & 24 & $55,81 \%$ \\
Jumlah & & 43 & $100 \%$ \\
\hline
\end{tabular}

Berdasarkan tabel 1: klasifikasi variabel regulasi diri dengan menggunakan $Z$ skor, hasil analisis menunjukkan bahwa sebagian besar mahasiswa yang memprogram skripsi yang bekerja paruh waktu memiliki tingkat regulasi diri yang rendah yaitu sebanyak 24 mahasiswa $(55,814 \%)$ dan sisanya sebanyak 19 mahasiswa $(44,186 \%)$ memiliki tingkat regulasi diri yang tinggi. Kesimpulan dari data di atas adalah sebagian besar mahasiswa skripsi, yang bekerja paruh waktu memiliki tingkat regulasi diri yang rendah.

\section{Analisis Deskriptif Stres Akademik}

Berikut tabel klasifikasi hasil penelitian dari variabel stres akademik:

Tabel 2. Klasifikasi dan Frekuensi Stres Akademik

\begin{tabular}{llll}
\hline Klasifikasi & Rumus & $f$ & $\%$ \\
\hline Tinggi & $Z>0$ & 22 & $48,84 \%$ \\
Rendah & $Z<0$ & 21 & $51,16 \%$ \\
Jumlah & & 43 & $100 \%$ \\
\hline
\end{tabular}

Berdasarkan tabel 2 menunjukkan bahwa klasifikasi variabel stres akademik dihitung dengan menggunakan $\mathrm{Z}$ skor, hasilnya menunjukkan bahwa sebagian besar mahasiswa skripsi, yang bekerja paruh waktu sebagian besar memiliki tingkat stres akademik yang tinggi yaitu sebanyak 22 mahasiswa $(51,16 \%)$ dan sisanya sebanyak 21 mahasiswa $(48,84 \%)$ memiliki tingkat stres akademik yang rendah. Kesimpulan dari data di atas adalah sebagian besar mahasiswa skripsi, yang bekerja paruh waktu memiliki tingkat stres akademik yang tinggi.

\section{Hasil Uji Hipotesis}

Berdasarkan hasil perhitungan korelasi Product Moment dari Pearson diperoleh hasil korelasi sebagai berikut:

Tabel 3. Analisi Korelasi Antara Regulasi Diri dan Stres Akademik

\begin{tabular}{lllll}
\hline Var X & Var Y & Sig $(\mathrm{p})$ & $\mathrm{r}_{\mathrm{xy}}$ & Ket \\
\hline $\begin{array}{l}\text { Regulasi } \\
\text { diri }\end{array}$ & Stres akademik & 0,005 & 0.425 & $\begin{array}{l}\text { Hipotesis } \\
\text { diterima }\end{array}$ \\
\hline
\end{tabular}


Berdasarkan tabel 3 menunjukkan hasil analisis menggunakan korelasi Product Moment dari Pearson, diperoleh koefisien korelasi $\left(\mathrm{r}_{\mathrm{xy}}\right)$ $-0,425$ dan signifikansi (p) 0,005 < 0,01. Artinya terdapat hubungan yang negatif sangat signifikan antara regulasi diri dengan stres akademik pada mahasiswa yang bekerja paruh waktu. Dapat disimpulkan: semakin tinggi regulasi diri maka semakin rendah stres akademik, begitu pula sebaliknya semakin rendah regulasi diri maka semakin tinggi stres akademik.

Berdasarkan hasil perhitungan korelasi analisis regresi sederhana diperoleh hasil sebagai berikut:

Tabel 4. Hasil Analisis Regresi Sederhana

\begin{tabular}{llllll}
\hline Var X & Var Y & $\begin{array}{l}\mathrm{R} \\
\text { quare }\end{array}$ & $f$ & Sig & $\mathrm{T}$ \\
\hline $\begin{array}{l}\text { Regulasi i } \\
\text { diri }\end{array}$ & $\begin{array}{l}\text { Stres aka- } \\
\text { demik }\end{array}$ & 0,213 & 11,082 & 0,002 & $-3,329$ \\
\hline
\end{tabular}

Berdasarkan tabel 4 menunjukkan hasil penghitungan analisis regresi sederhana antara variabel regulasi diri dengan variabel stres akademik diperoleh nilai $F_{\text {hitung }}$ sebesar 11,082 dengan signifikansi sebesar 0,002 . Hasil $\mathrm{f}_{\text {hitung }}$ memiliki signifikansi sebesar 0,002 (sig < 0,01) dengan nilai koefisien korelasi $t_{\text {hitung }}$ sebesar $-3,329$ maka terdapat pengaruh yang negatif antara variabel regulasi diri dengan variabel stres akademik. Besarnya nilai koefisien determinasi (R Square) sebesar 0,213, yang artinya bahwa regulasi diri memberikan sumbangan efektif terhadap stres akademik sebesar $21,3 \%$.

Hasil analisis korelasi product moment dan analisis regresi sederhana membuktikan: terdapat hubungan yang negatif antara regulasi diri dan stres akademik artinya, semakin tinggi tingkat regulasi diri maka semakin rendah tingkat stres akademik yang dimiliki mahasiswa. Begitu pula sebaliknya, apabila tingkat regulasi diri rendah maka stres akademik yang dimiliki semakin tinggi. Regulasi diri dapat menjadi prediktor naik-turunnya stress akademik mahasiswa yang sedang menger-jakan skripsi, dan bekerja paruh waktu. Berdasarkan analisis regresi sederhana, menunjukkan sumbangan efektif regulasi diri terhadap stres akademik sebesar $21,3 \%$, sisanya dipengaruhi oleh faktor-faktor yang lainnya yang tidak dilibatkan dalam penelitian ini.

\section{PEMBAHASAN}

Hasil penelitian menunjukkan bahwa sebagian mahasiswa yang memprogram skripsi, yang bekerja paruh waktu memiliki regulasi diri yang cenderung rendah. Artinya mahasiswa mengalami kesulitan untuk mengontrol dan mengatur diri dengan baik, sehingga berdampak pada ketidakmampuan membuat strategi-strategi maupun perenca-naan (planning) untuk setiap kegiatan yang dilakukan, yang terarah pada pencapaian tujuan. Regulasi diri yang rendah ditandai dengan ketidakmampuan untuk menentukan strategi-strategi tepat dan efektif yang sesuai dengan kemampuan ataupun keterampilan kinerja untuk mencapai tujuan yang telah ditetapkan, di satu sisi aspek regulasi diri merupakan hal penting yang dilakukan demi tercapainya tujuan yang ingin dicapai.

Menurut Schunk \& Zimmerman (1998) regulasi diri merupakan penggunaan suatu proses yang mengaktivasi pemikiran, perilaku dan perasaan yang terus menerus dalam upaya untuk mencapai tujuan yang telah ditetapkan. Menurut Hergenhann (1984) regulasi diri adalah kemampuan me-ngatur dan mengendalikan perilaku manusia. Menurut Zimmerman (1995) terdapat bebe-rapa aspek dalam regulasi diri diantaranya metakognisi yang meliputi merencanakan, mengorganisasi, mengukur diri dan meng-instruksi diri sebagai kebutuhan selama proses perlakuannya. Motivasi adalah fungsi dari kebutuhan dasar untuk mengontrol dan berkaitan dengan kemampuan yang ada pada setiap individu. Perilaku merupakan upaya untuk mengatur diri, menyeleksi dan me-manfaatkan maupun menciptakan lingkung-an yang mendukung aktivitas yang dilaku-kan. Kurangnya pengetahuan mahasiswa skripsi terhadap tekanan yang akan dihadapai apabila mahasiswa tersebut menyelesaikan skripsi dengan bekerja paruh waktu. Adanya ketidakseimbangan antara tujuan yang ingin dicapai dengan kemampuan regulasi diri yang dimiliki. Kurangnya pemahaman dan kemampuan untuk mengukur kemampuan diri dalam merencanakan dan menginstruksi diri sehingga berdampak pada pemilihan strategi-strategi yang tidak tepat dan tidak efektif. Selain itu, kurangnya upaya untuk mengatur perencanaan tujuan seperti penetapan prioritas dalam tujuan, sehingga menjadi salah satu penyebab pemilihan strategi yang kurang tepat. Sandar dan Cleary (2011) mengungkapkan bahwa sebagian besar mahasiswa 
cenderung melebih-lebihkan keterampilan yang dimiliki, sehingga dapat memiliki efek negatif pada pemilihan dan penggunaan strategi untuk mencapai tujuan.

Hasil penelitian ini juga memberikan bukti empiris bahwa stres akademik mahasiswa yang memprogram skripsi dalam kategori yang tinggi. Hasil ini sesuai dengan penelitian yang dilakukan Arsaningtias (2017) terhadap 221 mahasiswa, diketahui bahwa sebagian besar mahasiswa yang sedang menyelesaikan studinya mengalami stres berat. Salah satu faktor yang berpengaruh adalah regulasi diri, dikuatkan dengan hasil penelitian Kusumadewi (2011) yang menunjukkan bahwa individu yang tidak memiliki regulasi diri yang baik dapat menyebabkan individu tersebut tidak mampu mengontrol tingkah lakunya, sehingga kondisi tersebut dapat menyebabkan individu merasa tertekan dan stres.

Stres akademik ialah respon yang muncul karena terlalu banyaknya tuntutan dan tugas yang harus dikerjakan (Olejnik \& Holschuh (2007), selain itu stres akademik adalah stres yang muncul karena adanya tekanan-tekanan untuk menunjukkan prestasi dan keunggulan dalam kondisi persaingan akademik yang semakin meningkat sehingga mereka semakin terbebani oleh berbagai tekanan dan tuntutan (Alvin, 2007). Berdasarkan hal ini maka diduga mahasiswa yang sedang memprogram skripsi sekaligus bekerja paruh waktu maka dimungkinkan memiliki tuntutan dan tugas yang dirasakan semakin berat, sehingga dapat menimbulkan stres akademik, yang akan berdampak terhadap proses penyelesaian skripsi yang menjadi tugasnya.

Penelitian ini melibatkan responden, yaitu mahasiswa yang sedang menyusun skripsi dan juga sedang bekerja paruh waktu. Berdasarkan data yang diperoleh sebagian besar subjek penelitian melakukan kerja paruh waktu dengan durasi selama 6-9 jam perhari, hal ini dapat menjadi salah satu faktor stres akademik yang tinggi karena dapat mengganggu dalam proses pengerjaan skripsi. Kondisi ini relevan dengan peneli-tian sebelumnya yang menunjukkan bahwa terdapat pengaruh yang signifikan status kerja mahasiswa yakni kerja paruh waktu (part-time) terhadap aktivitas belajar (Mardelina, 2015). Hal tersebut dapat menunjukkan bahwa mahasiswa yang bekerja paruh waktu dapat mempengaruhi proses penyelesaian skripsi. Data penelitian diperoleh juga menyatakan bahwa mahasiswa memiliki tingkat regulasi diri yang rendah, hal ini menunjukkan ketidakseimbangan antara kemampuan yang dimiliki individu dalam menghadapi tuntutan dan tekanan stres akademik, dapat menjadi salah satu faktor dalam munculnya stres akademik.

Hasil penelitian juga menunjukkan bahwa terdapat hubungan negatif antara regulasi diri dengan stres akademik pada mahasiswa skripsi Universitas Negeri Malang yang bekerja paruh waktu. Artinya semakin rendah tingkat regulasi diri maka semakin tinggi stres akademik. Adanya hubungan negatif antara regulasi diri dengan stres akademik, sesuai dengan penelitian sebelumnya dengan responden mahasiswa Malaysia (Ramli, dkk., 2018). Implikasi dari temuan ini: mahasiswa yang sedang memprogram skripsi yang ingin bekerja paruh waktu mengukur kemampuan dirinya untuk menilai seberapa mampukah mahasiswa tersebut untuk meregulasi dirinya dengan baik, karena bila mahasiswa berfikir bahwa mereka tidak mampu untuk mengendalikan situasi cenderung mengalamai stres yang lebih besar. Hal tersebut sesuai dengan pernyatan dari Alvin (2007) yang menyatakan bahwa mahasiswa yang berfikir tidak dapat mengendalikan situasi dan kondisi cenderung akan mengalami stres yang lebih besar. Semakin besar kendali yang dipikir dapat dilakukan maka semakin kecil kemungkinan stres yang dialami. Dengan demikian, penting bagi mahasiswa untuk meningkatkan kemampuan untuk melakukan regulasi diri, agar mampu untuk mengelola stress yang akan terus terjadi dalam kehidupan sehari-hari maupun stress dalam konteks akademik.

Regulasi diri dapat mengurangi stres dan frustasi serta mempermudah pelaksanaan strategi pemecahan masalah atau koping (Ayduk, dkk., 2000), oleh karena itu terdapat hubungan antara stres akademik dan nilai akademik mahasiswa dikualifikasikan dari strategi koping stres dan motivasi (Sruthers, 2000), dengan kata lain kemampuan kinerja dan hasil ujian merupakan penyebab utama stres akademik mahasiswa, hal tersebut dapat dikontrol dengan melatih salah satunya dengan melatih regulasi diri sebagai strategi koping (Ramli, dkk., 2018).

Regulasi diri merupakan kemampuan untuk mengontrol, mengarahkan dan mengatur perilaku untuk mencapai tujuan yang ingin dicapai. Relevan dengan hal ini hasil penelitian Sandars dan Cleary (2011) mengungkapkan bah- 
wa mahasiswa kedokteran yang berhasil dalam mengerjakan tugas yang diberikan (pengambilan darah) menunjukkan bahwa mahasiswa tersebut menetapkan tujuan dan membuat rencana selama proses pengerjaan tugas, memantau proses dan mengevaluasi tingkat keberhasilan dalam kinerja.

Regulasi diri yang efektif akan dapat mengatasi tekanan yang diakibatkan dari tuntutan-tuntutan baik itu skripsi, dari tempat kerja dan dari lingkungan sosial seperti tuntutan dari orangtua, dari teman sebaya dan lain-lain. Mahasiwa yang memiliki regulasi diri yang tinggi, maka akan menetapkan tujuan dengan strategi-strategi yang efektif serta mengatur perilaku sedemikian rupa sehingga dapat mencapai tujuan, hingga berdampak pada capaian akdemik. Menurut Kitsantas (2008) siswa yang berprestasi tinggi dengan skor tes tinggi menetapkan tujuan dengan proses yang lebih strategis, memantau kemajuan sendiri dan menggunakan evaluasi diri untuk membuat penilaian tentang kinerja pada tes. Merujuk pada uraian di atas dapat disimpulkan bahwa regulasi diri merupakan kunci meminimalkan stres akademik, sebaliknya perperan positif untuk meningkatkan unjuk kerja dan prestasi tinggi.

Hasil penelitian menggunakan analisis regresi sederhana juga menguatkan hasil penelitian sebelumnya, bahwa regulasi diri dapat memprediksi varian stres akademik. Regulasi diri memiliki sumbangan pengaruh terhadap stres akademik sebesar $21,3 \%$, sedangkan 78,7 $\%$ dipengaruhi oleh faktor-faktor lain yang tidak dilibatkan dalam penelitian ini. Implikasi penting dari temuan ini adalah stres akademik dapat diminimalkan ketika mahasiswa yang sedang memprogram skripsi dan bekerja paruh wak$\mathrm{tu}$, piawai mengelola diri dengan efektif, antara lain dengan tetep fokus terarah pada tujuan dan mengatur perilakunya ke arah pencapaian tujuan. Selanjutnya, pengaturan waktu juga menjadi penting ketika mahasiswa mengerjakan dua tugas (menulis skripsi dan bekerja paruh wak$\mathrm{tu}$ ). Direkomendasikan pada penelitian selanjutnya untuk meneliti model teoritik stress akademik mahasiswa yang memprogram skripsi dengan melibatkan variabel lain selain regulasi diri, misalnya koping stres, dukungan sosial, resiliensi akdemik, sehingga diperoleh penjelasan yang lebih komprehensip terkait fenomena stress akaemik mahasiswa yang sedang mem-

\section{KESIMPULAN DAN SARAN Kesimpulan}

Hasil penelitian menunjukkan bahwa: regulasi diri mahasiswa skripsi yang bekerja paruh waktu, sebagian besar mahasiswa memiliki regulasi diri dalam kategori rendah, sedangkan stres akademik sebagian besar memiliki stres akademik dalam kategori tinggi. Ada hubungan negatif yang signifikan antara regulasi diri dengan stres akademik mahasiswa yang memprogram skripsi yang bekerja paruh waktu. Artinya semakin rendah regulasi diri yang dimiliki maka semakin tinggi stres akademik yang dirasakan. Regulasi diri memiliki sumbangan pengaruh terhadap stres akademik sebesar $21,3 \%$, sementara itu masih terdapat sisanya 78,7\% dipengaruhi oleh faktor-faktor lain yang tidak dilibatkan dalam penelitian ini.

\section{Saran}

Merujuk pada temuan penelitian maka disarankan kepada (1) mahasiswa yang sedang memprogram skripsi dan bekerja paruh waktu disarankan untuk meningkatkan regulasi diri dengan menilai tehadap kemampuan diri dalam mengontrol dan mengatur diri, sehingga mampu membuat perencanaan dan menyusun strategi-strategi yang tepat untuk mengatur diri dan membagi waktu antara mengerjakan skripsi dengan bekerja. Selain itu, dengan melakukan latihan terus menerus khususnya melatih regulasi diri sehingga benar-benar menjadi skill sebagai upaya efektif mereduksi stress akademik dan meningkatkan capaian kinerja akademik yang ditargetkan (2) untuk penelitian selanjutnya dapat menyempurnakan penelitian ini, dengan melibatkan variabel penting yang diduga dapat menjelaskan stres akademik mahasiswa yang sedang memprogram skripsi seperti: koping stres, dukungan sosial, resiliensi akademik, sehingga problematik empiris yaitu stres akademik pada mahasiswa yang sedang memprogram skripsi dan bekerja paruh waktu dapat dijelaskan secara komprehensif. Rekomendasi yang lain perlu dilakukan penelitian pengembangan untuk merancang model pelatihan regulasi diri (self regulation training model) untuk mengurangi stres akademik pada mahasiswa, khususnya yang sedang memprogram skripsi dan bekerja paruh waktu. 


\section{REFERENSI}

Agustia, D. (2008). Hubungan antara Regulasi Diri dengan Stres pada Mahasiswa yang Berstatus Menikah di Universitas Syiah Kuala. Skripsi. Banda Aceh: Fakultas Kedokteran Universitas Syiah Kuala

Alvin, N. O. (2007). Handling Study Stress: Panduan agar Anda Bisa Belajar Bersama Anak-anak Anda. Jakarta: Elex Media Komputindo.

Arnett J. J. (2000). Emerging Adulthood: A Theory of Development From the Late Teens Through Twenties. American Psychological Asociation, 55(5), 469-480. DOI: 10.1037/0003-066X.55.5.469

Arnett, J. J. (2004). Emerging Adulthood: The Winding Road From the late Teens Trough the Twenties. Oxford University Press

Arsaningtias, R. P. (2017). Analisis Faktor Stressor yang Berhubungan dengan Stres Mahasiswa Program Studi S1 yang Melaksanakan Skripsi di Universitas Airlangga Surabaya. Skripsi. Surabaya: Fakultas Keperawatan Universitas Airlangga Surabaya

Ayduk, Mendoza-Denton, Mischel, Downey, Peake, \& Rodriguez. (2000). Regulating The Interpersonal Self: Strategic Self-Regulation for Coing with Rejection Sensitivity. Journal of Personality and Social Psychology, 79(5), 776-792. Dari: http//doi. org/10.1037/0022-3514.79.5.776

Beaton, D. E., \& dkk. (2000). Guidelines for the process of cross-cultural adaptation of self-report measures. Spine, 25(24), 3186319

Ghufron, N, \& Risnawati, R. (2012). Gaya Belajar. Yogyakarta: Pustaka Pelajar

Govaerst \& Gregoire. (2004). Stressfull Academic Situations: Study On Appraisil Variabels in Adolescence. British Journal of Clinical Psychology, 54(4),261-271. DOI: 10.1016/j. erap.2004.05.001

Kadapatti, M. G., \& Vijayalaxmi A.H.M., (2012). Stressors of academic stress--a study on pre-university students. Indian Journal of Scientific Research, 3(1), 171-175

Kitsantas, A., Winsler, A., \& Huie, F. (2008). Self Regulation As Predictor Academic Success. Journal of Medical Academic, 20(1), 42-68. DOI: $10.4219 /$ jaa-2008-867

Lin Y. M., \& Chen F. S. (2009). Academic Stress Inventory of Student at Universities and College of Technology. World Transaction on Engineering and Technology Education, $7(2), 157-162$

Mardelina, E. (2015). Pengaruh Kerja Part Time terhadap Aktivitas Belajar Mahasiswa. Skripsi. Yogyakarta: Universitas Negeri Yogyakarta

Olejnik, S. N. L., \& Holschuh, J. P. (2007). College rules!2nd Edition How TI study survive, and succeed in college. Ten Speed Press

Rahman, N. I.A, Ismail, S., Tengku Ain, N., Atikah, N.F., Aisyah, S., Wan Elena, P., Islam, M.D., \& Haque, M. (2013). Stress among Preclinical Medical Students of University Sultan Zainal Abidin. Journal of Applied Pharmaceutical,3(11), 076-081. DOI: 10.7324/ JAPS.2013.31113

Ramli, N, H., Alavi, M., Seyed, A, M., Ahmadi, A. (2018). Academic Stress and Self-Regulation Among University Student in Malaysia: Mediator Role of Mindfulness. Behavioral Sciences, 8(1), 12. DOI: 10.3390/ bs8010012

Sandar, J., \& Cleary, T, J. (2011). Self-regulation theory: Applications to medical education: AMEE Guide No. 58. Journal Medical Teacher, 33(11), 875-886. DOI: 10.3109/0142159X.2011.595434

Sruthers, C, W., Perry, R,P., \& Menec, V, H. (2000). An Examination of the Relationship Among Academic Stres, Coping, Motivation and Performace In College. Human Science Press Inc., 41(5), 581-592. DOI: 10.1023/ AA1007094931292

Sudjana, N. (1998). Dasar-Dasar Proses Belajar Mengajar. Bandung: Sinar Baru Algesindo

Zimmerman, B.J. (2000). Attaining self regulation: a social cognitive perspective. Handbook of self regulation. New York: University of New York 